American Journal of Applied Sciences 9 (1): 47-53, 2012

ISSN 1546-9239

(C) 2012 Science Publications

\title{
The Impact of Human Resource Practices and Organizational Citizenship Behaviors on Firm Performance
}

\author{
${ }^{1}$ Davood Babaei, ${ }^{1}$ Aminah Ahmad, ${ }^{1}$ Khairuddin Idris, \\ ${ }^{1}$ Zoharah Omar and ${ }^{2}$ Hamid Rahimian \\ ${ }^{1}$ Department of Professional Development and Continuing Education, \\ Faculty of Educational Studies, Universiti Putra Malaysia \\ 43400 UPM Serdang, Selangor, Malaysia \\ ${ }^{2}$ Department of Educational Administration, \\ School of Psychology and Education, \\ Allameh Tabataba'i University, Iran
}

\begin{abstract}
Problem statement: The examination of organizational citizenship behaviors as the mediating variable through which human resource practices affect firm performance is still scarce. Approach: This study examined the mediation effects of organizational citizenship behaviors on the relationships between selected human resource practices and firm performance. The human resource practices studied were reward and performance appraisal practices and firm performance was studied in terms of quality of services. Data were collected from a sample of 179 branches of two banks in Tehran, Iran. The participants in this study included 176 managerial employees, 352 non-managerial employees and 871 customers. To achieve these objectives a mediation model was tested using structural equation modeling procedure to examine if the hypothesized model fit the data. Results: The results showed that organizational citizenship behaviors fully mediated the relationships between reward practices and quality of services and partially mediated the relationships between performance appraisal practices and quality of services. Conclusion/Recommendations: The findings of this study suggest that human resource practices play a critical role in enhancing employees' organizational citizenship behaviors and firm performance. Organizational citizenship behaviors mediate the effects of reward and performance appraisal practices on service quality. To improve service quality, employers should improve reward and performance appraisal practices since these practices have an impact on employees' organizational citizenship behaviors which in turn would affect service quality.
\end{abstract}

Key words:Human resource practices, organizational citizenship behaviors, service quality, firm performance

\section{INTRODUCTION}

A considerable amount of literature has been published on human resource practices (HRP) and firm performance. There are many studies focusing on relationships between HRP and organizational performance improvement (Gooderhama et al., 2008; Liu et al., 2007). These studies reveal that HRP have a positive effect on firm performance. Most of the literature on the relationships between HRP and firm performance explained the direct relationships of the practices on performance (Chan et al., 2004; Gooderhama et al., 2008; Guerrero and Didier, 2004; Lee et al., 2005; Liu and Chow, 2007; Mavondo et al., 2005; Ngo et al., 2008; Wood et al., 2006; Wright and
Kehoe, 2008). Researchers have investigated the effects of HRP on organizational citizenship behaviours (OCBs) (Guest et al., 2004; Zhang et al., 2008). The importance of OCBs have been emphasized by among others, Asgari et al. (2008a; 2008b) and other researchers have illustrated the positive impact of OCBs on firm performance (Koys, 2001; Podsakoff et al., 2009; Podsakoff et al., 2000; Yoon, 2009).

Morrison (1996) in his model discussed how OCBs provide a critical link between HRP and firm's level of customer service, one of the dimensions of firm performance. According to this model, OCBs could have a positive impact on service quality. Organization should ensure the existence of social exchanges, identification with organizational objectives and

Corresponding Author: Aminah Ahmad, Department of Professional Development and Continuing Education,

Faculty of Educational Studies, University Putra Malaysia, 43400 UPM Serdang, Selangor, Malaysia 
employee empowerment to encourage the display of citizenship behavior among employees. With the existence of these three conditions, there is a greater possibility that employees will engage in more OCBs and, hence, deliver higher service quality. It is also argued that a firm's overall human resource practices such as approach to selection of employees and evaluation and reward practices will affect the extent of citizenship behavior that employees display. However more specifically, OCBS can influence managerial evaluation of performance, judgment regarding pay raises, promotion, firm performance (Podsakoff et al., 2000) and employee behaviors (outside of task performance or organizational citizenship behaviors) can influence organizational effectiveness (Devonish and Greenidge, 2010).

Although a study conducted by Sun et al. (2007) has shown that OCBs have mediating effects on the practiceperformance relationships, the examination of OCBs as the mediating variable through which HRP affect firm performance is still scarce. Hence, this study further investigated the mediating role of OCBs in the relationships between HRP (reward and performance appraisal practices) and firm performance (quality of services) and tested the following hypotheses:

$\mathrm{H} 1$ : There is a positive relationship between performance appraisal practices and OCBs

$\mathrm{H} 2$ : There is a positive relationship between reward practices and OCBs

H3: There is a positive relationship between performance appraisal practices and quality of services

H4: There is a positive relationship between reward practices and quality of services

H5: OCBs mediate the relationship between performance appraisal practices and quality of services

H6: OCBs mediate the relationship between reward practices and quality of services

\section{MATERIALS AND METHODS}

Sample: The sample of this study consisted of 179 branches from two Iranian banks in Tehran, a public and a private bank. The data were gathered from 104 branches from the public bank and 75 from the private bank. From each branch, three personnel (a manager or an assistant manager and two non-managerial employees) and five customers served as the source of data. A total of 176 managers or assistant managers, 352 non-managerial employees and 871 customers participated in this study. The branches and the employees were selected using simple random sampling and the customers using systematic sampling.
Measurements: Three sets of questionnaires were developed for gathering data in this study, the first for managers and assistant managers, the second for nonmanagerial employees and the third for customers. Both the questionnaires for managers and assistant managers and employees comprised 3 parts: (1) performance appraisal practices ( 5 items adapted from Lepak and Snell, 2002; Zhang et al., 2008); (2) reward practices (4 items adapted from Lepak and Snell, 2002; Zhang et al., 2008) and (3) OCBs (11 items adopted from Podsakoff and MacKenzie, 1994). The questionnaire for customers assessed their perceptions of service quality and it comprised 15 items adapted from Chen (2009). All constructs were measured using five-point Likert scale ranging from strongly disagree (1) to strongly agree (5).

Data analysis: Two types of data analysis, descriptive analysis and inferential analysis were used in this study. Descriptive statistics including means and standard deviations and zero-order correlations between variables were computed. Structural Equation Modeling (SEM) was used to assess direct and indirect relationships among variables. AMOS version 16.0 was used to perform these analyses. The structural equation models integrate a measurement model and a structural model (Iacobucci, 2008). Since 100-150 participants are sufficient to conduct structural equation modeling (Ding et al., 1995), the number of participants $(\mathrm{n}=179)$ in this study is suitable for the use of SEM.

\section{RESULTS}

Description of study variables: Table 1 shows the means, standard deviations, Cronbach alpha values of the variables in the model and correlation coefficients between these variables. The Cronbach alpha values for all variables are greater than 0.80 , which means that the reliabilities of the measuring scales are acceptable. The Cronbach alpha value is 0.87 performance appraisal, 0.84 for reward practices, 0.88 for organizational citizenship behavior and 0.94 for quality of services. Also the results of the bivariate correlation analyses show that all correlation coefficients are significant at $\alpha=0.05$.

Table 1: Means, Standard Deviations, Reliabilities and Correlations

\begin{tabular}{lllllll}
\hline Variable & M & SD & Perf. App. & Rewards & OCBs & SQ \\
\hline Perf. app. & 2.9600 & 0.56779 & 0.87 & & & \\
Reward practices & 2.8203 & 0.59571 & $0.496^{* *}$ & 0.84 & & \\
OCB & 3.7504 & 0.41356 & $0.435^{* *}$ & $0.518^{* *}$ & 0.88 & \\
SQ & 4.0750 & 0.32743 & $0.538^{* *}$ & $0.575^{* *}$ & $0.667^{* *}$ & 0.94 \\
\hline
\end{tabular}

Note: $\mathrm{N}=179 *$ : Correlation is significant at the 0.05 level. **: Correlation is significant at the 0.01 level. Cronbach alpha reliability values are shown in bold. Perf. App.= Performance Appraisal; SQ = Service Quality 


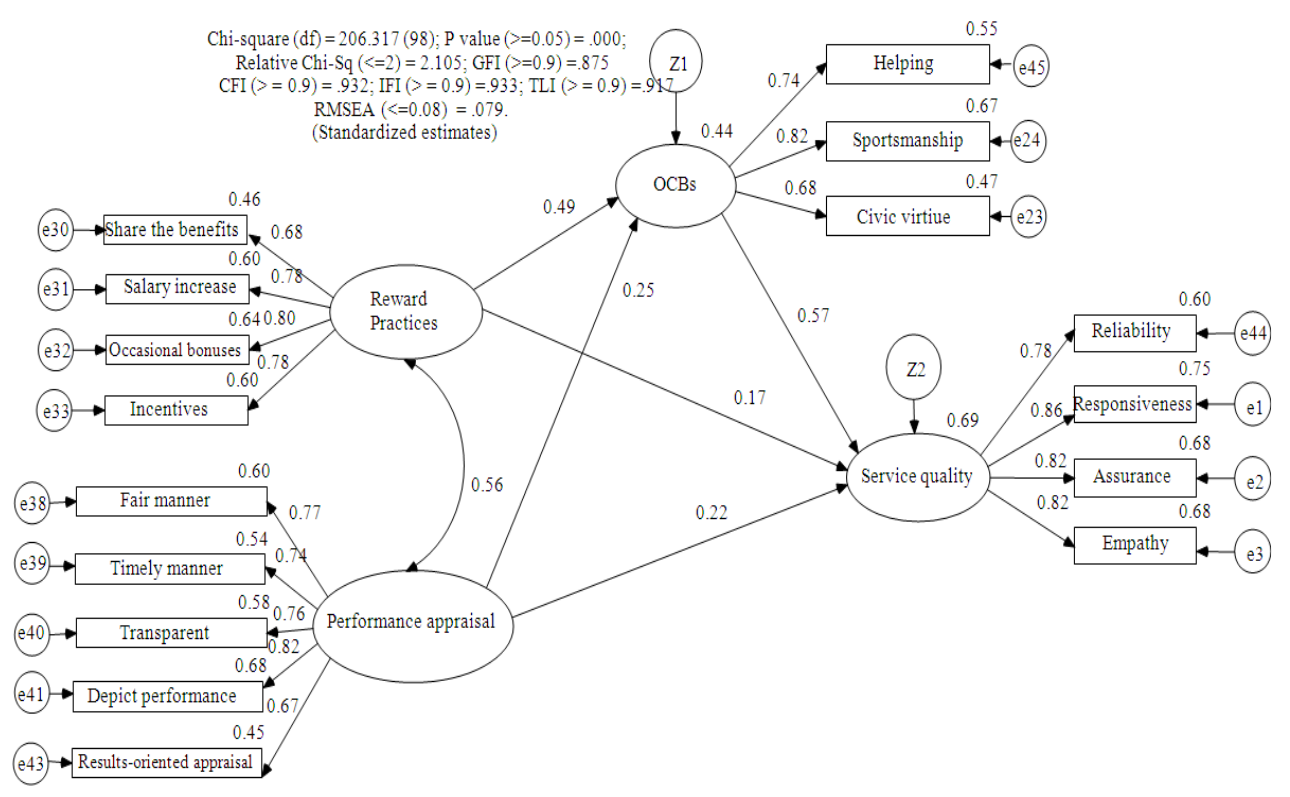

Fig. 1: Estimated path coefficients of the hypothesized model

Evaluation of the measurement model: confirmatory factor analysis: Before evaluating the fit of the path model Fig. 1, it was necessary to define a measurement model to verify that the measurement variables included to reflect the four unobserved constructs (reward practices, performance appraisal, OCBs and service quality) do so in a reliable manner. The overall fit of a measurement model was determined by the Confirmatory Factor Analysis (CFA). CFA also determine the explained variances and standardized residuals for the measurement variables and the adequacy of the factor loadings. After conducting CFA it was confirmed that three factors served as indicators of OCBs and four factors as indicators of service quality. Based on the results of CFA, two items from performance appraisal and three items from service quality were dropped because they had low factor loadings.

Path analysis with latent variables: SEM is usually used in model evaluation situations, involving strictly confirmatory, alternative models and model generating approaches (Chou and Bentler, 2002). A path analysis with latent constructs was conducted to examine the direct and indirect effects of the independent variabl es on the dependent variable as well as the effect of the mediating variable on the relationships between the independent variables and the dependent variable. This study assessed the relationships between the independent variables, rewards and performance appraisal and the dependent variable, service quality, with OCBs as the mediator Fig. 1. According to the model it is hypothesized that HRP are related to firm performance (service quality), all of them directly and indirectly, as well as mediated by OCBs. The 16 items were included to represent the four factors of rewards, performance appraisal, OCBs and firm performance after modifications were made following confirmatory factor analysis.

Evaluation of the mediation path model vs. the indirect path model: After the modified measurement model has been confirmed, the fit of the structural path model can be evaluated (Ho, 2006). The factor structure confirmed in the measurement model is used as the foundation for the path model. The posited model for this study contains two models: (1) the mediation model, which incorporates all identified path linking the four factors and (2) the indirect model, in which the two direct paths linking human resource practices to service quality are not estimated. As both these models are nested and possess different degrees of freedom, their goodness-of-fit are directly compared via multimodel analysis. Table 2 presents the chi-square goodness-offit statistics, baseline comparisons fit indices and model comparison statistics for the mediation and indirect path models. Although the chi-square values for both path models are statistically significant, both models yield poor fit by the chi-square goodness-of-fit test, the baseline comparison fit indices of IFI, TLI and CFI for both models are above 0.900 (0.909-0.933). These values show the improvement in fit of both models relative to the null model (Ho, 2006). 
Am. J. Applied Sci., 9 (1): 47-53, 2012

Table 2: Parameters of the models

\begin{tabular}{llllllllll}
\hline Model & CMIN & DF & P & CMIN/DF & RMSEA & GFI & CFI & IFI & TLI \\
\hline Mediation & 206.317 & 98 & 0.000 & 2.105 & 0.079 & 0.875 & 0.932 & 0.933 & 0.917 \\
Indirect & 220.346 & 100 & 0.000 & 2.203 & 0.080 & 0.868 & 0.924 & 0.925 & 0.909 \\
\hline
\end{tabular}

Table 3: Nested Model Comparisons (Assuming mediation model to be correct)

\begin{tabular}{llllllll}
\hline Model & DF & CMIN & P & NFI delta-1 & IFI delta-2 & RFI rho-1 & TLI rho2 \\
\hline Indirect model & 2 & 14.571 & 0.001 & 0.008 & 0.009 & 0.007 & 0.007 \\
\hline
\end{tabular}

Table 4: Standardized regression weights in the models

\begin{tabular}{|c|c|c|c|c|c|}
\hline DV & & IV & $\begin{array}{l}\text { Mediation } \\
\text { Model }\end{array}$ & $\begin{array}{l}\text { Indirect } \\
\text { Model }\end{array}$ & $\begin{array}{l}\text { Direct } \\
\text { Model }\end{array}$ \\
\hline $\mathrm{OCBs}$ & $<--$ & Rewards & $0.489^{* * *}$ & $0.512 * * *$ & \\
\hline OCBs & $<--$ & Performance appraisal & $0.248^{*}$ & $0.312 * * *$ & \\
\hline Service quality & $<--$ & OCBs & $0.569^{* * *}$ & $0.850 * * *$ & \\
\hline Service quality & $<--$ & Performance appraisal & $0.220 * *$ & & $0.362 * * *$ \\
\hline Service quality & $<--$ & Rewards & 0.167 & & $0.445 * * *$ \\
\hline
\end{tabular}

Note: $*: \mathrm{p}<0.05 ; * *: \mathrm{p}<0.01, * * *: \mathrm{p}<0.001$

The root mean square error of approximation (RMSEA) fit index for mediation and indirect path models are 0.079 and 0.080 , respectively. Values ranging from 0.05-0.08 are acceptable (Ho, 2006). Thus, the acceptable RMSEA values for the mediation and indirect path models suggest that the fit of these two models is adequate. As shown in Table 2 both models fit the data well and according to the nested model comparisons (Table 3) although both models fit the data relatively well, the mediation model represents a significantly better fit than the indirect model and this mediation model is preferred.

The unidirectional arrows pointing to the latent factors of OCBs and service quality (Fig. 1) represent the unexplained (residual) variance for these two factors. According to the squared multiple correlations for this hypothesized model, $56 \%$ of the variation in OCBs is unexplained; alternatively, $44 \%$ of the variance is accounted for by the joint HRP predictors. Similarly, $31 \%$ of the variation in the service quality is unexplained; alternatively, $69 \%$ of the variance is accounted by the joint influences of the predictors of HRP and OCBs.

Hypothesis testing: The hypothesized mediation model was tested with maximum likelihood estimation. The regression weights of the mediation, indirect and direct models are presented in Table 4 . The path coefficients in this model indicate that rewards and performance appraisal are positively linked to OCBs. These results provide support for $\mathrm{H} 1$ and $\mathrm{H} 2$.

Mediation role: The results of mediation effects can be interpreted as follows. In this mediation model, rewards and performance appraisal have direct significant relationships with OCBs, $\beta=0.49$ and $\beta=0.25$, respectively and OCBs has a direct significant relationship with service quality ( $\beta=0.57$ ). Besides the direct relationships, rewards and performance appraisal are related indirectly to service quality through OCBs.

Partial mediation: In partial mediation hypothesis all three paths: $\mathrm{X} \rightarrow \mathrm{M}(\beta \mathrm{mx})$ and both $\mathrm{X} \rightarrow \mathrm{Y}$ ( $($ yx.m) and $M \rightarrow Y \quad(\beta y m . \quad x)$ are significant when considered simultaneously (Mathieu and Taylor, 2006). Since in the mediation model, performance appraisal has a significant relationship with OCBs $(\beta=0.25)$ and service quality $(\beta=0.22)$ and OCBs has a significant relationship with service quality $(\beta=0.57)$, OCBs has a partial mediation effect in the relationship between performance appraisal and service quality. As shown in Table 4, all the conditions for confirmation of partial mediation effect of OCBs have been met.

Full mediation: According Mathieu and Taylor (2006), in the relationship $\mathrm{X} \rightarrow \mathrm{M} \rightarrow \mathrm{Y}$, a hypothesis of full mediation is supported when $\beta \mathrm{yx}, \beta \mathrm{mx}$ and $\beta \mathrm{ym}$ are significant and if neither $\beta y x . m$ nor $\beta y m . x$ is significant. In the direct model, rewards have a significant relationship with service quality $(\beta=0.45)$. When these conditions are satisfied, then the data are consistent with the hypothesis of full mediation (Mathieu and Taylor, 2006). As shown in Table 4, since all the conditions for full mediation are met, OCBs has a mediation effect on the relationship between reward practises and service quality.

Table 5 shows the direct, indirect and total effects of human resource practices and OCBs on service quality in the mediation model. In sum, the findings indicate that OCBs fully mediates the effects of reward practises and partially mediates the effects of performance appraisal practises on service quality. Hence, H3, H4, H5 and H6 are supported. 
Am. J. Applied Sci., 9 (1): 47-53, 2012

Table 5: Standardized effects in mediation model

\begin{tabular}{lllll}
\hline Effects & & Rewards & $\begin{array}{l}\text { Performance } \\
\text { appraisal }\end{array}$ & OCBs \\
\hline Direct & Service quality & 0.167 & 0.220 & 0.569 \\
Indirect & Service quality & 0.278 & 0.141 & 0.000 \\
Total & Service quality & 0.445 & 0.361 & 0.569 \\
\hline
\end{tabular}

\section{DISCUSSION}

Human capital can provide competitive advantage to a firm and its employees are integral to its success. Hence, researchers interested in managing human capital have increasingly focused on human resource practices as instrumental in building the human capital that makes up resources and capabilities (Wright and Kehoe, 2008). Since firms are searching for means to develop sources of competitive advantage, investigators and experts have looked at firms' human resources (Wright et al., 2001). In view of the fact that employees' skills, employees' behaviors and HRP are significantly linked to firm performance (Bhattacharya et al., 2005) and acknowledging that human resource can be an organizational source of competitive advantage (Park et al., 2003), human resource practitioners need to design appropriate practices for managing human resource.

The results of this study indicate that HRP positively affect the performance of private and public banks in Tehran, Iran. In particular, these relationships are mediated through employees' organizational citizenship behaviors, which shed some light on the processes through which HRP affect the quality of service. Hence, this research not only demonstrates that HRP have a positive influence on quality of service but also articulates the mechanisms through which HRP improve service quality. This study also verified that OCBs have positive and direct effects on service quality as an indicator of firm performance. The results support Morrison (1996) argument that OCBs provide a critical link between a firm's human resource practices and the quality of customer service. Similarly, Sun et al. (2007) illustrated in their research that HRP was related to organizational performance and their findings indicate that a partially mediating role of OCBs exists in the relationships between HRP and organizational performance.

The findings of this study, using data from a developing country such as Iran, support the contention that there exist relationships between service quality and firms' human resource practices. Specifically, the findings of this study suggest that reward practises, performance appraisal practices and organizational citizenship behaviors have effects on quality of services. Also, the findings suggest that reward practises and performance appraisal practises have effects on organizational citizenship behaviors of employees.

However, we should acknowledge that some organizations adopt HRP conditionally. For example, according to the economic approach, organizations adopt HRP that are economically beneficial to them, or based on the alignment approach view, organizations adopt these practices only when the practices are in line with the organizations' strategic objectives (Subramony, 2006).

\section{CONCLUSION}

In sum, the findings of this study suggest that HRP play a critical role in enhancing organizational citizenship behaviors and firm performance. OCBs mediate the effects of rewards and performance appraisal on service quality.

This study was limited to examining managerial and non-managerial employees' perceptions of HRP and behavior outcomes and customers' perceptions of service quality of Iranian banks. The banks were selected by random sampling from branches of two banks in Tehran city. Accordingly, the generalization of the findings is limited to these two banks.

Another theoretical limitation to this study is that HRP can be influenced by factors outside the organization, such as economic, cultural and political factors (Fombrum et al., 1984). Therefore, the findings of this study may not be generalised to other countries, although we do believe that these findings may be applicable to other countries with similar economic, cultural and political characteristics.

Several suggestions are recommended for future research. To date, only a handful of research have examined the effects of HRP on OCBs and firm performance. The focus for future research would be on the investigation of the effects of economic, cultural and political factors on HRP, OCBs and firm performance. In addition, investigations should also be conducted among employees from different sectors besides the banking sector for further verifications.

\section{REFERENCES}

Asgari, A., A.D. Silong, A. Ahmad and B.A. Samah, 2008a. The relationship between transformational leadership behaviors, organizational justice, leader-member exchange, perceived organizational support, trust in management and organizational citizenship behaviors. Eur. J. Sci. Res., 2: 227-242. 
Asgari, A., A.D. Silong, A. Ahmad and B.A. Samah, 2008b. The relationship between organizational characteristics, task characteristics, cultural context and organizational citizenship behaviors. Eur. J. Econ., Finance Admin. Sci., 13: 94-107.

Bhattacharya, M., D.E. Gibson and D.H. Doty, 2005. The effects of flexibility in employee skills, employee behaviors and human resource practices on firm performance. J. Manage., 31: 622-640. DOI: $10.1177 / 0149206304272347$

Chan, L.L.M., M.A. Shaffer and E. Snape, 2004. In search of sustained competitive advantage: The impact of organizational culture, competitive strategy and human resource management practices on firm performance. Inter. J. Hum. Resource Manage., $\quad 15: \quad 17-35 . \quad$ DOI: 10.1080/0958519032000157320

Chen, S.H., 2009. Establishment of a performanceevaluation model for service quality in the banking industry. Service Industries J., 29: 235-247. DOI: 10.1080/02642060802295034

Chou, C. P. and P.M. Bentler, 2002. Model modification in structural equation modeling by imposing constraints. Compu. Statistics Data Analysis, 41: 271-287. DOI: 10.1016/S016794730200097-X

Devonish, D. and D. Greenidge, 2010. The effect of organizational justice on contextual performance, counterproductive work behaviors and task performance: Investigating the moderating role of ability-based emotional intelligence. Inter. J. Selection Assessment, 18: 75-86. DOI: 10.1111/j.1468-2389.2010.004

Ding, L., W.F. Velicer and L.L. Harlow, 1995. Effects of estimation methods, number indicators per factor and improper solutions on structural equation modeling fit indices, Structural Equation Modeling: Multidisciplinary J., 2: 119-144. DOI: 10.1080/10705519509540000

Fombrum, C.J., N.M. Tichy and M.A. Devanna, 1984. Strategic Human Resource Management. 1st Edn., John Wiley and Sons, New York, ISBN: 0471810797, pp: 499.

Gooderhama, P., E. Parryb and K. Ringdalc, 2008. The impact of bundles of strategic human resource management practices on the performance of European firms. J. Hum. Resource Manage., 19: 2041-2056. DOI: 10.1080/09585190802404296

Guerrero, S. and V.R.B. Didier, 2004. Highinvolvement practices and performance of French firms. Inter. J. Hum. Resource Manage., 15: 14081423. DOI: $10.1080 / 0958519042000258002$
Guest, D., N. Conway and P. Dewe, 2004. Using sequential tree analysis to search for bundles of HR practices. Hum. Resource Manage. J., 14: 79-96. DOI: 10.1111/j.1748-8583.2004.tb00113.x

Ho, R., 2006. Handbook of Univariate and Multivariate Data Analysis and Interpretation with SPSS. 1st Edn., Chapman and Hall/CRC, Boca Raton, ISBN: 1584886021, pp: 406.

Iacobucci, D., 2008. Mediation Analysis. 1st Edn., SAGE, London, ISBN: 141292569X, pp: 85.

Koys, D.J., 2001. The effects of employee satisfaction, organizational citizenship behavior and turnover on organizational effectiveness: A unit-level, longitudinal study. Personnel Psychol., 54: 101114. DOI: $10.1111 /$ j.1744-6570.2001.tb00087.x

Lee, S.H., P.H. Phan and E. Chan, 2005. The impact of HR configuration on firm performance in singapore: A resource-based explanation. Inter. J. Hum. Resource Manage., 16: 1740-1758. DOI: 10.1080/09585190500239465

Lepak, D.P. and S.A. Snell, 2002. Examining the human resource architecture: The relationships among human capital, employment and human resource configurations. J. Manage., 28: 517-543. DOI: $10.1177 / 014920630202800403$

Liu, B., X. Zhu and N. Tang, 2007. Organizational innovation and human resource practice: A view of strategic human resource bundling. Proceedings of the International Conference on Service Systems and Service Management, Jun. 9-11, IEEE Xplore Press, Chengdu, pp: 1-4. DOI: 10.1109/ICSSSM.2007.4280086

Liu, S. and I.H. Chow, 2007. In search of the best human resource practices in China's chain stores. Proceedings of the International Conference on Wireless Communications, Networking and Mobile Computing, Sept. 21-25, IEEE Xplore Press, Shanghai, pp: 4505-4511. DOI: 10.1109/WICOM.2007.1110

Mathieu, J.E. and S.R. Taylor, 2006. Clarifying conditions and decision points for mediational type inferences in organizational behavior. J. Organ. Behav., 27: 1031-1056. DOI: 10.1002/job.406

Mavondo, F.T., J. Chimhanzi and J. Stewart, 2005. Learning orientation and market orientation: Relationship with innovation, human resource practices and performance. Eur. J. Market., 39: 1235-1263. DOI: 10.1108/03090560510623244

Morrison, E.W., 1996. Organizational citizenship behavior as a critical link between hrm practices and service quality. Hum. Resource Manage., 35: 493-512. DOI: $10.1002 /($ SICI)1099050X(199624)35:4<493::AID-HRM4>3.0.CO;2-R 
Ngo, H.Y., C.M. Lau and S. Foley, 2008. Strategic human resource management, firm performance and employee relations climate in China. Hum. Resource Manage, 47: 73-90. DOI: 10.1002/hrm.20198

Park, H.J., H. Mitsuhashi, C.F. Fey and I. Bjorkman, 2003. The effect of human resource management practices on Japanese MNC subsidiary performance: A practical mediating model. Inter. J. Hum. Resource Manage., 14: 1391-1406. DOI: 10.1080/0958519032000145819

Podsakoff, N.P., S.W. Whiting, P.M. Podsakoff and B.D. Blume, 2009. Individual-and organizationallevel consequences of organizational citizenship behaviors: A meta-analysis. J Applied Psychol., 94: 122-141. DOI: 10.1037/a0013079

Podsakoff, P.M. and S.B. MacKenzie, 1994. Organizational citizenship behaviors and sales unit effectiveness. J. Market. Rese., 31: 351-363. DOI: $10.2307 / 3152222$

Podsakoff, P.M., S.B. MacKenzie, J.B. Paine and D.G. Bachrach, 2000. Organizational citizenship behaviors: A critical review of the theoretical and empirical literature and suggestions for future research. J. Manage., 26: 513-563. DOI: $10.1177 / 014920630002600307$

Subramony, M., 2006. Why organizations adopt some human resource management practices and reject others: An eploration of rationales. Hum. Resource Manage, 45: 195-210. DOI: 10.1002/hrm.20104
Sun, L.Y., S. Aryee and K.S. Law, 2007. Highperformance human resource practices, citizenship behavior and organizational performance: A relational perspective. Acad. Manage. J., 50: 558577. DOI: 10.5465/AMJ.2007.25525821

Wood, S., D. Holman and C. Stride, 2006. Human resource management and performance in UK call centres. Br. J. Industrial Relat., 44: 99-124. DOI: 10.1111/j.1467-8543.2006.00489

Wright, P.M. and R.R. Kehoe, 2008. Human resource practices and organizational commitment: A deeper examination. Asia Pacific J. Hum. Resources, 46: 6-20. DOI: 10.1177/1038411107086540

Wright, P.M., T.M. Gardner, L.M. Moynihan, H.J. Park and B. Gerhart et al., 2001. Measurement error in research on human resources and firm performance: Additional and suggestions for future research. Personnel Psychol., 54: 875-901. DOI: 10.1111/j.1744-6570.2001.tb00235.x

Yoon, C., 2009. The effects of organizational citizenship behaviors on ERP system success. Comput. Hum. Behav., 25: 421-428. DOI: 10.1016/j.chb.2008.10.004

Zhang, Z., D. Wan and M. Jia, 2008. Do highperformance human resource practices help corporate entrepreneurship? The mediating role of organizational citizenship behavior. J. High Technol. Manage. Res., 19: 128-138. DOI: 10.1016/j.hitech.2008.10.005 